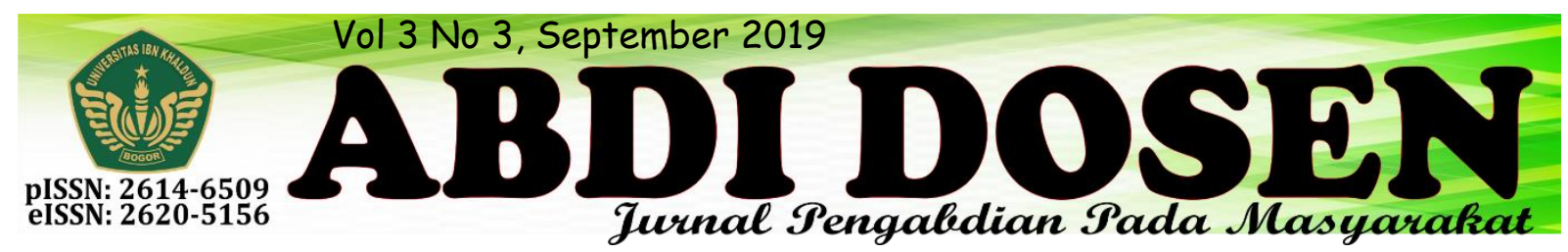

\title{
MENINGKATKAN MUTU PENDIDIKAN, KESEHATAN, DAN KESADARAN BERAGAMA DI KP. DUKUH LEBAK DESA CIBADAK
}

\author{
N.A. Rumiasih ${ }^{1}$, Via Laila Lutfiah ${ }^{2}$ \\ rumiasih@uika-bogor.ac.id ${ }^{1}$ \\ onlyvie1511@gmail.com $^{2}$
}

Fakultas Ekonomi dan Bisnis Universitas Ibn Khaldun ${ }^{1}$, Mahasiswa KKN Kelompok 13 Tahun $2018^{2}$

\begin{abstract}
ABSTRAK
Kuliah Kerja Nyata (KKN) merupakan salah satu bentuk pengamalan Tri Dharma Perguruan Tinggi. KKN kelompok 13 ditempatkan di sebuah Desa yang bernama Cibadak. Khususnya pada wilayah RW 08. Berdasarkan hasil survey kelompok, ditemukan beberapa permasalahan yang terjadi. Teruatama pada lingkungan, pendidikan, kesehatan, dan tentang keagamaannya. Pada tatarang lingkungan yang tidak bersih dan sumber air yang sangat minim menimbulkan lingkungan yang tidak sehat. Selain itu, rendahnya minat baca tidak menutup kemungkinan jumlah lulusan SDpun hanya sedikit. Terbukti dari hasil data yang ditemukan bahwa lulusan atau tamatan SD hanya berjumlah 819 orang diwilayah desa Cibadak. Terlebih di RW 08, sedikit sekali yang melanjutkan pendidikan. Tidak sedikit dari mereka putus sekolah hanya untuk berkerja sebagai buruh bangunan. Selain itu, kurangnya guru agama pada wilayah tersebut sangat berpengaruh terhadap akhlak manusia kepada manusia lainnya. Karena hidup lebih indah dengan tatakrama. Kemudian, melihat volume sampah yang tidak tahu mau dibuang kemana kami menyediakan 12 tong sampah yang siap disebar pada titik tertentu untuk meminimalisir pembuangan sampah. Hal ini karena didesa tersebut masih kurangnya kesadaran dan sarana prasarana tentang pemberdayaan lingkungan, yang menjadi perhatian adalah dengan kondisi desa yang berada diwilayah perkotaan dengan tingkat polusi yang tinggi dan kurangnya sarana atau fasilitas yang mendukung pelaksanaan pemberdayaan lingkungan. Adapun metode pendekatan yang digunakan adalah: a) Pendekatan tokoh masyarakat, b) Pendekatan Religius, c) Pendekatan Karakter.
\end{abstract}

\section{Kata Kunci : Pendidikan, Kesehatan, Agama}

\section{PENDAHULUAN}

Desa Cibadak merupakan bagian dari Kecamatan Ciampea, Kabupaten Bogor, Provinsi Jawa Barat. Luas wilayah Desa Cibadak adalah 114 Ha. Pelaksanaan KKN Tematik Universitas Ibn Khaldun Bogor kelompok 13 ditempatkan di lokasi Kp. Dukuh RW 08 yang berjumlah 3 RT (RT 01, RT 02, dan RT 03). Berdasarkan hasil observasi yang dilakukan oleh kelompok 13 didapat permasalahan dasar di Desa tersebut. Pada titik minimnya kesadaran itu ternyata terderevasi langsung pada bidang - bidang lain, yaitu kesehatan, pendidikan, dan agama.

\section{Keadaan Geografis}

Desa Cibadak merupakan salah satu Desa diwilayah Kecamatan Ciampea Kabupaten Bogor, dengan luas wilayah 114 Ha, 188-200 diatas permukaan laut yang terbagi dalam 2 (dua) dusun, 8 Rukun 
Warga (RW), dan 38 Rukun Tetangga (RT). Batas wilayah Desa Cibadak adalah sebagai berikut:

\begin{tabular}{|c|c|c|}
\hline No. & Arah & Berbatasan \\
\hline 1. & Utara & $\begin{array}{c}\text { Kehutan Gunung } \\
\text { Cibodas }\end{array}$ \\
\hline 2. & Selatan & Desa Cicadas \\
\hline 3. & Barat & Desa Giri Mulya \\
\hline 4. & Timur & Desa Bojongrangkas \\
\hline
\end{tabular}

Pemanfaatan lahan atau penggunaan tanah didesa Cibadak adalah sebagai berikut:

\begin{tabular}{|c|l|c|}
\hline No. & \multicolumn{1}{|c|}{ Keterangan } & Luas/Ha \\
\hline 1. & $\begin{array}{l}\text { Perumahan/ } \\
\text { Pemukiman dan } \\
\text { Pekarangan }\end{array}$ & 77 \\
\hline 2. & Sawah/Ladang & 12 \\
\hline 3. & Empang & 1 \\
\hline 4. & $\begin{array}{l}\text { Pemakaman/ } \\
\text { Kuburan }\end{array}$ & 2 \\
\hline 5. & Jalan & 6 \\
\hline 6. & Perkantoran & 0,25 \\
\hline 7. & $\begin{array}{l}\text { Lapangan } \\
\text { Olahraga }\end{array}$ & - \\
\hline 8. & $\begin{array}{l}\text { Tanah/Bangunan } \\
\text { Pendidikan }\end{array}$ & 0,8 \\
\hline
\end{tabular}

Pada bidang lingkungan ada beberapa permasalahan yang terjadi diarea kampung Dukuh Lebak. Yang paling menonjol adalah masalah kebersihan ditandai dengan volume sampah yang berserakan dan pembuangan sampah ke sungai. Hal ini terjadi karena tidak adanya tempat pembuangan akhir dan petugas yang mengelola sampah. Adapun solusi sementara yang dilakukan oleh warga adalah dengan membakar sampah tersebut. Namun hal itu bukanlah solusi terbaik, karena pembakaran sampah dapat mencemari udara sekitar ditambah lagi keadaan kampung Dukuh Lebak yang cukup gersang.

\section{Kondisi Masyarakat}

Jumlah penduduk Desa Cibadak sampai akhir bulan Desember Tahun 2014 tercatat sebanyak 11.018 jiwa terdiri dari:

\begin{tabular}{|c|c|}
\hline Jenis kelamin & Jumlah \\
\hline Laki - laki & 5899 \\
\hline Perempuan & 5618 \\
\hline
\end{tabular}

Secara umum kondisi sosial politik dan ketentraman serta ketertiban di Desa Cibadak RW 08 kurang aman dan kurang tertib. Dikarenakan tidak adanya pos ronda dan tidak adanya penjagaan malam diwilayah tersebut.

Adapun tingkat pendidikan penduduk Desa adalah sebagai berikut:

\begin{tabular}{|c|l|c|}
\hline No. & $\begin{array}{c}\text { Tingkat Pendidikan } \\
\text { Penduduk }\end{array}$ & Jumlah \\
\hline 1. & TK & 175 \\
\hline 2. & SD / MI & 819 \\
\hline 3. & MTS / SLTP & 120 \\
\hline 4. & MA / SLTA & 1250 \\
\hline 5. & D2 - D3 & 9 \\
\hline 6. & S1 / Sarjana & 32 \\
\hline \multicolumn{2}{|c|}{ Desa Cibadak khususnya diwilayah }
\end{tabular}

RW 08 Kp. Dukuh Lebak tidak memiliki sarana prasarana pendidikan yang memadai. Permasalahan pendidikan yang ada di Kp. Dukuh Lebak disebabkan oleh jarak tempuh sarana pendidikan yang cukup jauh dan kurangnya minat masyarakat untuk melanjutkan kejenjang pendidikan pada tingkat yang lebih tinggi. Baginya berkerja adalah tujuan utama dari hidup. Mayoritas masyarakat Kp. Dukuh Lebak adalah lulusan SD /MI sampai SMP/SLTP sedangkan untuk tingkat MA/SLTA masih sulit untuk ditemukan terlebih pada tingkat sarjana. Walaupun dengan keadaan yang seperti itu antusias belajar agama anak-anak cukup tinggi dicerminkan melalui jumlah murid TPA (Taman Pendidikan Al - Qur'an) Nurul Yaqin yang mencapai angka 50 orang. 


\section{Bidang Ekonomi}

Keadaan mata pencaharian penduduk Desa Cibadak adalah sebagai berikut:

\begin{tabular}{|c|c|c|}
\hline No. & Keterangan & Jumlah \\
\hline 1. & PNS & 85 \\
\hline 2. & ABRI & 28 \\
\hline 3. & Wiraswasta & 305 \\
\hline
\end{tabular}

\begin{tabular}{|c|c|c|}
\hline 4. & Tani & 38 \\
\hline 5. & Buruh Tani & 56 \\
\hline 6. & Pertukangan & 150 \\
\hline 7. & Pensiunan & 42 \\
\hline 8. & Jasa & 200 \\
\hline 9. & Lain - lain & 955 \\
\hline
\end{tabular}

\section{METODE PENGABDIAN}

Metode Penyelenggaran

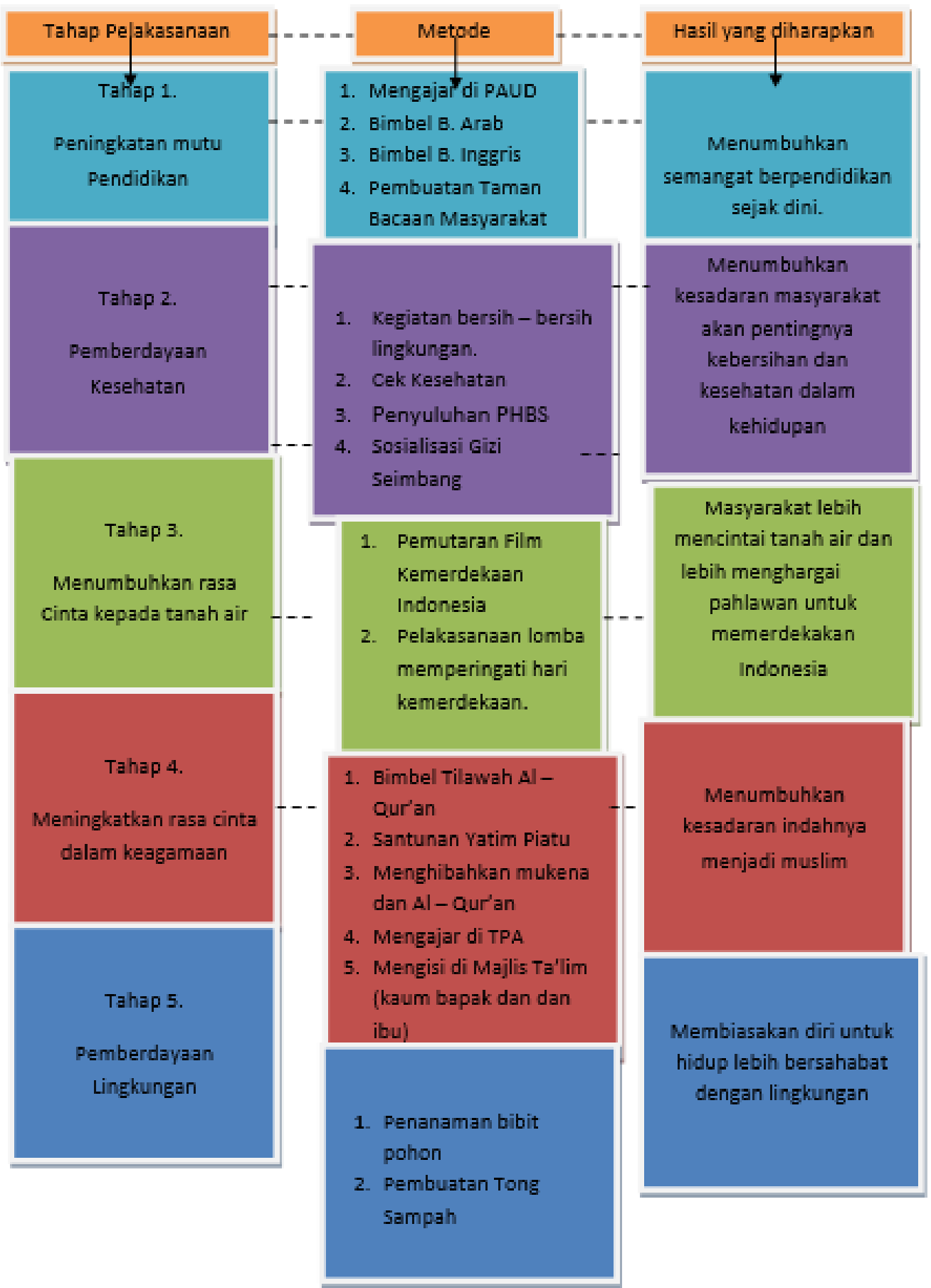




\section{Jadwal Kegiatan}

\begin{tabular}{|c|c|c|c|c|c|c|}
\hline \multirow{2}{*}{ No } & \multirow{2}{*}{ Kegiatan } & \multicolumn{5}{|c|}{ Minggu ke } \\
\hline & & 1 & 2 & 3 & 4 & 5 \\
\hline 1. & $\begin{array}{l}\text { Perkenalan dengan masyarakat Desa } \\
\text { Cibadak }\end{array}$ & & & & & \\
\hline 2. & Penyusunan Rencana Kegiatan & & & & & \\
\hline 3. & Sosialisasi Rencana Kerja & & & & & \\
\hline 4. & Survei lokasi mengajar PAUD dan TPA & & & & & \\
\hline 5. & Mengikuti Pengajian Majlis Ta'lim & & & & & \\
\hline 6. & $\begin{array}{l}\text { Pertemuan dengan lurah dan Rw } 08 \\
\text { Desa Cibadak }\end{array}$ & & & & & \\
\hline 7. & $\begin{array}{l}\text { Membatik Bersama ibu - ibu PKK Desa } \\
\text { Cibadak }\end{array}$ & & & & & \\
\hline 8. & Kerja Bakti Lingkungan RW 08 & & & & & \\
\hline 9. & $\begin{array}{l}\text { Pengajaran di PAUD Pelangi dan TPA } \\
\text { Nurul Yaqin }\end{array}$ & & & & & \\
\hline 10. & Mengajar Tilawah $\mathrm{Al}$ - Qur'an & & & & & \\
\hline 11. & Mengisi Pengajian Kaum Bapak / Ibu & & & & & \\
\hline 12. & Bimbingan belajar B. Inggris & & & & & \\
\hline 13. & Bimbingan Belajar B. Arab & & & & & \\
\hline 14. & $\begin{array}{l}\text { Membantu Persiapan } 17 \text { Agustus RW } \\
\text { 08 Desa Cibadak }\end{array}$ & & & & & \\
\hline 15. & $\begin{array}{l}\text { Pemutaran } \quad \text { Film } \quad \text { Kemerdekaan } \\
\text { Indonesia }\end{array}$ & & & & & \\
\hline 16. & $\begin{array}{l}\text { Ngeliwet bareng warga RW } 08 \text { Desa } \\
\text { Cibadak }\end{array}$ & & & & & \\
\hline 17. & $\begin{array}{l}\text { Mengikuti Pelatihan Pendataan Desa } \\
\text { Cibadak }\end{array}$ & & & & & \\
\hline 18. & Sosialisasi Gizi Seimbang & & & & & \\
\hline 19. & Pendataan Desa Cibadak & & & & & \\
\hline 20. & Perayaan 17 Agustus SDN Dukuh & & & & & \\
\hline 21. & Cek Kesehatan & & & & & \\
\hline 22. & Penyuluhan PHBS SDN Dukuh & & & & & \\
\hline 23. & Penanaman Bibit Pohon & & & & & \\
\hline 24. & Jalan Sehat Desa Cibadak & & & & & \\
\hline 25. & Pembuatan Tong Sampah & & & & & \\
\hline 26. & Peresmian Taman Bacaan Masyarakat & & & & & \\
\hline 27. & Santunan Yatim/Piatu & & & & & \\
\hline 28. & $\begin{array}{l}\text { Pemberian Mukena dan Al - Qur'an Ke } \\
\text { Masjid Nurul Yaqin }\end{array}$ & & & & & \\
\hline 29. & $\begin{array}{l}\text { Closing KKN Tematik Posko } 13 \text { di RW } \\
\text { 08 Desa Cibadak }\end{array}$ & & & & & \\
\hline
\end{tabular}




\section{Metode Pendekatan}

Pendekatan yang dilakukan pada kegiatan KKN Tematik antara lain:

1. Tokoh Masyarakat

Tokoh masyarakat sebagai penghubung dengan masyarakat yang dapat mempermudah komunikasi dan kelancaran kegiatan KKN yang dilaksanakan. Kegiatan KKN yang disetujui dan dihimbau oleh tokohpun membuat membuat kegiatan $\mathrm{KKN}$ direspon dengan baik oleh masyarakat (Hendarto, 2017), karena masyarakat memiliki kemampuan untuk mempengaruhi masyarakat itu sendiri untuk melakukan kegiatan. (Najoan, 2013)

2. Pendekatan Religius

Pendekatan yang menggunakan nilainilai agama sebagai basis kegiatan, pengalaman kegiatan, rasa tanggung jawab, dan pengetahuan. (Ramchmawati, 2010). Masyarakat Kp. Dukuh Lebak termasuk cukup aktif mengikuti kegiatan keagamaan yang membuat pendekatan religius menjadi hal yang efektif agar dapat menjalankan program yang mengandung unsur keislaman.

3. Pendekatan Karakter

Pendekatan berdasarkan karakter masyarakat yang menandakan kemajemukan sifat dan prilaku serta prinsip hidup. Pemahaman terhadap perbedaan tersebut harus ada demi keberlangsungan program selama KKN berlangsung.

\section{Partisipasi Masyarakat dalam Pelaksanaan Program}

Partisipasi masyarakat pada kegiatan KKN Tematik UIKA adalah sebagai berikut:
1. Menyediakan lokasi posko sebagai pusat kegiatan KKN kelompok 13.

2. Merekomendasikan lokasi program akselerasi pendidikan.

3. Menyediakan sarana dan prasarana kegiatan 17 Agustus.

4. Mempersiapkan lokasi penghijauan untuk penanaman pohon.

5. Mempersiapkan tempat untuk pengajaran pengajian dan bimbingan belajar.

6. Mempersiapkan lokasi Taman Bacaan Masyarakat.

7. Antusias yang tinggi terhadap semua program kerja KKN tematik UIKA posko 13.

\section{Langkah Evaluasi}

Evaluasi yang akan dilakukan terdiri dari;

1. Evaluasi Proses

Evaluasi proses, yaitu evaluasi yang berkaitan langsung dengan perencanaan dan pelaksanaan serta monitoring kegiatan. Evaluasi proses dilakukan setiap pekan bersama dengan tokoh masyarakat Kp. Dukuh Lebak.

2. Evaluasi Hasil

Evaluasi hasil, dilaksanakan setelah pelaksanaan program disertai dengan analisa dampak yang dirasakan. Evaluasi hasil ditujukan untuk melihat proses taman baca,apakah berpengaruh dengan minat baca masyarakat atau tidak.

3. Evaluasi Dampak

Evaluasi dampak, yang akan dilakukan 6 (enam) bulan setelah pelaksanaan pembinaan. Evaluasi dampak diarahkan untuk melihat efektivitas kegiatan taman baca di Kampung Dukuh. 


\section{REALISASI PROGRAM}

Berikut adalah capaian program yang dicanangkan melalui program-program yang telah direncanakan:

\section{Bidang Pendidikan}

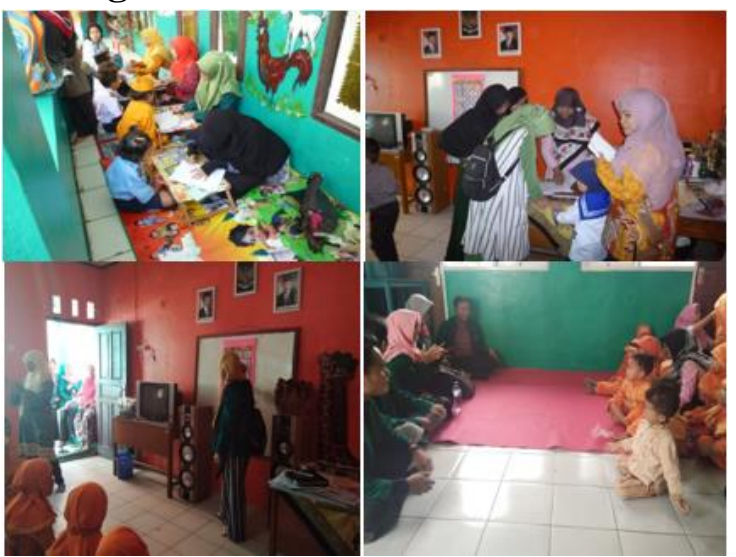

Pengajaran di PAUD Pelangi



Taman Bacaan Masyarakat

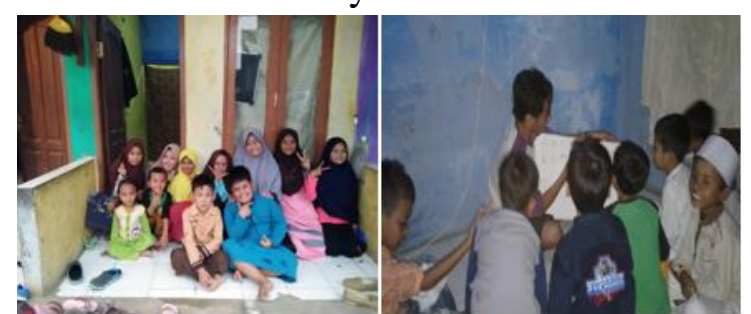

Bimbingan Belajar Bahasa Inggris

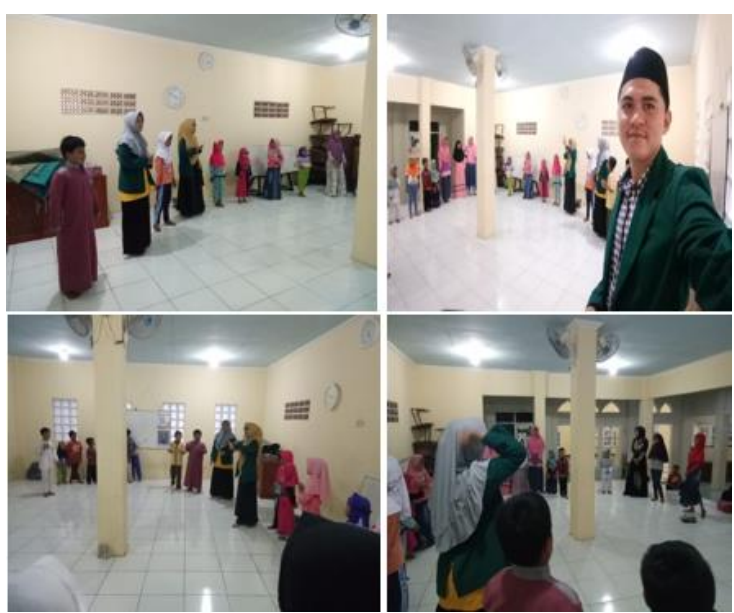

Bimbingan Belajar Bahasa Arab

\section{Bidang Kesehatan}

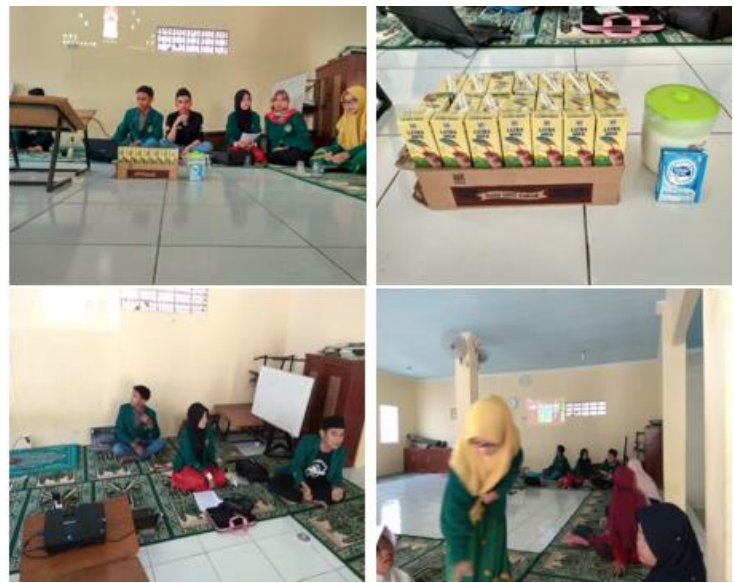

Penyuluhan / Sosialisasi Gizi

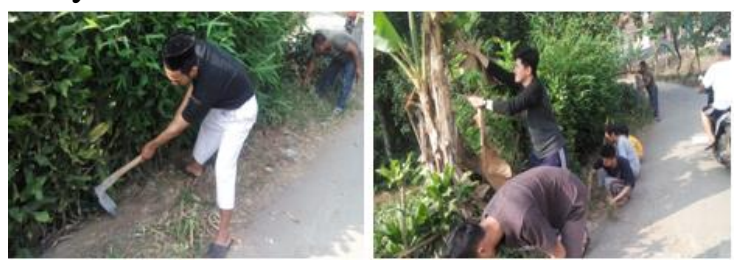

Kegiatan bersih - bersih lingkungan (Gotong Royong)

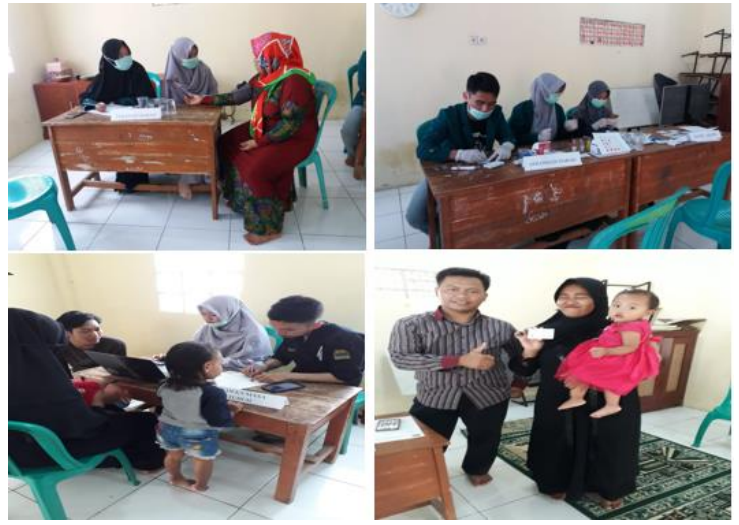

Cek Kesehatan 


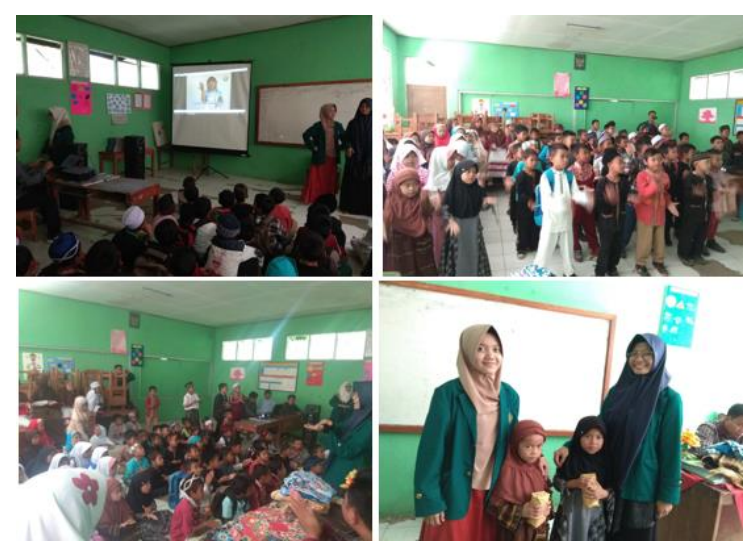

PHBS SDN Dukuh
Bidang Agama

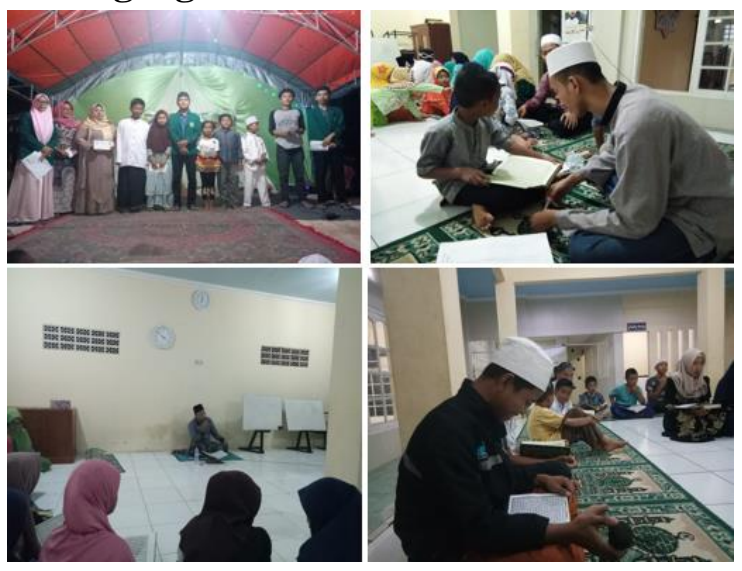

Pengajian

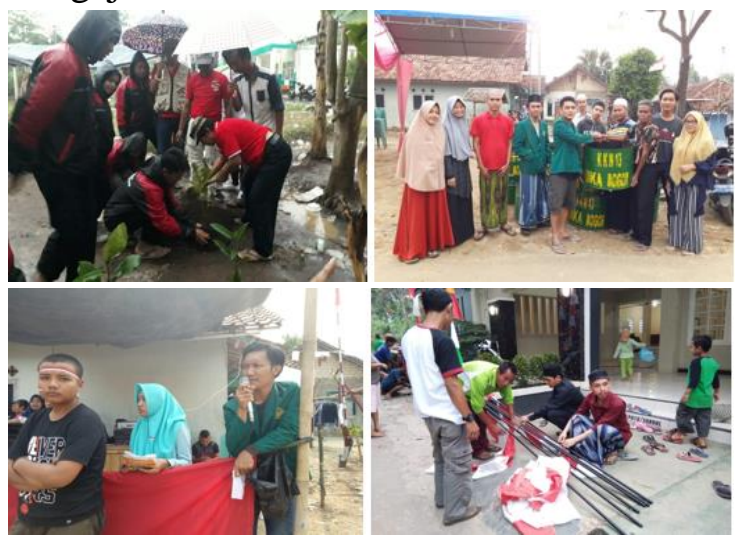

HUT Kemerdekaan

\section{KESIMPULAN}

Kuliah Kerja Nyata (KKN) memiliki kemanfaatan luar biasa bagi para calon sarjana untuk lebih mengenal kehidupan masyarakat dan segala problematika yang dihadapi sehingga calon sarjana mampu mengaplikasikan segala bidang ilmu yang telah didapatkannya selama perkuliahan dikampus. Berdasarkan hasil evaluasi dari kegiatan KKN kelompok 13 yang terletak di Desa Cibadak RW 08 berjalan dengan baik dan lancar. Kegiatan ini dapat berjalan dengan lancar karena kerjasama yang baik dari masyarakat desa, para donator, dan pihak Universitas. Adapun kegiatan yang kami jalankan yang teratasi permasalahannya berkaitan dengan:

a. Bidang Pendidikan

Kegiatan Belajar Mengajar (KBM) di PAUD terjadwal setiap hari mulai pkl.

07.30 s.d 10.15 Wib. Berkonstribusi di kelas A dan B dan tidak hanya pengajaran namun juga memberikan metode dan lagu - lagu baru anak sehingga proses pembelajaran menjadi lebih hidup. Untuk mengatasi kesulitan belajar dan menambah wawasan pemebalajaran diluar sekolah warga RW 08 maka dibuka bimbingan belajar berkaitan dengan pelajaran B. Arab dan B. Inggris yang terjadwal. Pada pekan kedua dan ke tiga B. Inggris pkl. 18.30 s.d. pkl. 19.30 bertempat diPosko 13 setiap hari dan pekan ketiga dan keempat B. Arab hanya dihari sabtu pkl. 16.30 s.d. 17.30 bertempat di Majlis Nurul Yaqin. Selain itu melihat rendahnya minat baca yang terdapat diwilayah RW 08, kami membuat 
Taman Bacaan Masyarakat (TBM) untuk umum yang berlokasi di Majlis Ta'lim Nurul Yaqin.

b. Bidang Kesehatan

Pada bidang kesehatan banyak sekali problematika yang ditemukan, diantaranya kurangnya masukan makanan yang bergizi, jumlah volume sampah yang membeludak dan terbuang disembarang tempat, sehingga kami menanggulanginya dengan cara memberikan penyuluhan / sosialisasi Gizi Seimbang untuk warga yang terlaksana pada Kamis 16 Agustus 2018. Pelaksanaan penyuluhan kesehatan dilakukan pada pukul 09.00 WIB. Adapun tempat pelaksanaan penyuluhan kesehatan yaitu di Majelis Nurul Yaqin RW 08 desa Cibadak. Dan melakukan gotong royong membersihkan lingkungan RW 08 pada 12 Agustus 2018. Untuk menambah wawasan hidup bersih dan sehat maka diadakannya PHBS untuk pelajar SD kelas 1, 2, dan 3 di SDN Dukuh pada Jum'at, 31 Agustus 2018, pukul 08.3011.00 WIB di SDN Dukuh. Dan Cek Kesehatan pada wilayah RW 08 pada Senin, 27 Agustus 2018. Pelaksanaa penyuluhan kesehatan dilakukan pada pukul 09.00 WIB. Berlokasi di Majelis Nurul Yaqin RW 08 desa Cibadak. Antusiasme warga sangat baik, bahkan diluar wilayah RW 08 pun ikut cek kesehatan yang diberikan cuma - cuma (Gratis).

c. Perayaan Hari Ulang Tahun Kemerdekaan Indonesia

Perayaan HUT RI dilaksanakan pada 17 Agustus 2018 di RW 08 Desa Cibadak dengan berbagai jenis perlombaan disiang hari dan pemutaran film oleh peserta KKN posko 13 tentang kemerdekaan Indonesia dimalam hari bersama warga RW 08 Desa Cibadak yang berlokasi di halaman posko 13 dan ditutup dengan ngeliwet bareng warga.

d. Bidang Keagamaan

Kegiatan keagamaan diposko 13 berkaitan dengan bimbingan belajar membaca Al - Qur'an (Tilawah Al Qur'an) tiap 2x dalam 1 minggu. Selasa malam dan sabtu malam berlokasi di Majlis Nurul Yaqin ditujukan kepada remaja wilayah RW 08 melihat krisis bacaannya dari tajwid dan makharijul hurufnya masih kurang baik serta mengenalkan lagu - lagu dalam membaca Al - Qur'an. Selain itu, bidang keagamaan juga berkontribusi dalam Majlis Ta'lim baik bapak bapak maupun Majlis Ta'lim ibu - ibu. Yang terjadwal satu minggu sekali setiap Rabu pagi pkl. 08.00 s.d. selesai MT. Kaum Ibu dan Rabu malam ba'da Isya MT. Kaum bapa wilayah RW 08 Desa Cibadak. Selain itu bidang keagamaan juga melakukan kegiatan dalam proses belajar mengajar di TPA Nurul Yaqin karena kurangnya guru agama dengan mengenalkan metode lain yang biasa dilakukan setiap hari pkl. 16.30 s.d. 17.30 terkecuali hari sabtu dan minggu. Dan melihat tidak adanya Al - Qur'an dan mukena dimesjid Nurul Yaqin maka kami memberikan $25 \mathrm{Al}$ - Qur'an dan 5 pasang mukena guna memfasilitasi kebutuhan warga dalam beribadah. Serta mengadakan santunan yatim/piatu di wilayah RW 08 Desa Cibadak guna mengenalkan indahnya berbagi dengan sesama. Acara santunan dan pemberian simbolis Al - Qur'an dan mukena pada acara closing KKN posko 13 dihalaman posko 13 pada senin malam, 03 September 2018.

e. Pemberdayaan Ligkungan 
Melihat jumlah volume sampah yang banyak namun tidak ditemukannya tempat pembuangan sampah dan titik terkahir pembuangan sampah, kami berinisiatif untuk membuat tong pembuangan sampah yang diletakkan pada titik tertentu di wilayah RW 08. Pemberian ini diberikan secara simbolis

\section{SARAN}

Sebagai evaluasi dan upaya perbaikan dalam penyelenggaraan program Kuliah Kerja Nyata (KKN) yang akan datang, baik bagi panitia penyelenggara, peserta, Dewan Pembimbing Lapangan, maupun masyarakat sebagai sasaran KKN, maka kami memberikan saran untuk Desa Cibadak agar kiranya lebih memprioritaskan terhadap lingkungan yang masih membutuhkan kebersihan dari

\section{REFERENSI}

https://akhmadsudrajat.wordpress.com/200 8/02/14/pendekatan-sosial-dalamkegiatan-kkn/

\section{Administrasi Profil Desa Cibadak}

E journal “Acta Diurna” Volume VI. No. 3 Tahun 2017 Peranan Komunikasi Tokoh Masyarakat Dalam Meminimalisir Kesenjangan Sosial Di Kelurahan Mampang Kota Depok Jawa Barat

\section{Oleh Bella Najoan, Debby D.V. Kawengian, Stefi H. Harilama Volume 02 Nomor 01, Maret 2018}

pada senin, 03 September 2018 pkl. 17.00. Selain itu, melihat keadaan wilayah RW 08 Desa Cibadak yang cukup gersang maka kami mengadakan penghijauan pada wilayah tersebut. Penghijauan ini dilakasanakan pad Minggu, 02 September 2018.

jumlah volume sampah yang membeludak tersebar di sebarang tempat, kemudian mengutamakan air bersih pada tempat atau daerah yang tertinggal. Sehingga tidak akan ada daerah yang tertinggal dan kumuh. Semoga segala hal yang telah dilakukan bernilai ibadah dan menjadi amal saleh, serta senantiasa diterima dan diridhoi oleh Allah SWT.

\section{Pemberdayaan Masyarakat Dan Lingkungan Dalam Rangka Peningkatan Pola Hidup Sehat Di Kp. Gunung Kapur Desa Bojong Indah}

Herawati1, Ade Muhammad, Sakinah Fitri Volume 02 Nomor 01, Maret 2018 Meningkatkan Mutu Pendidikan Dan Kesehatan Di Desa Ciseeng Zahrotunni'mah1, Ahmad Fathani, Adi Prasetyo 